\title{
Efficiency and Acceptability of a Customized e-learning Platform in a Philippine State University and College
}

\author{
Rolando Real Codilan \\ Faculty, College of Computer Studies \\ Eastern Samar State University Main Campus, Borongan City Philippines \\ roland.r.codilan@gmail.com
}

\begin{abstract}
The purpose of this study is to scrutinize the impact of efficiency of the software on students and acceptability to use e-learning Tool in their education. This study used a descriptive evaluative method of research in order to obtain an overall sense of the data being analyze in the e-learning tool for the College of Computer Studies in terms of efficiency and acceptability towards using the system. The data gathered in each criterion will be described for the technology acceptance and efficiency of the elearning Tool. The instrument used was based on (ISO 9126) Software Product Quality and (IBM) Usability Satisfaction. ISO 9126 and IBM standards serves as a framework or model for providing worldwide acceptable software qualities required for software evaluation. Findings: Data was gathered systematically and given careful consideration, analysis and interpretation using appropriate statistical tools as to come up with the following results; Based on the gathered data from the respondents for the level of efficiency of the e-learning tool the variables were rated as 4.7 Strongly Agree (SA) in general. For the extent of acceptability of the e-learning it also obtained the average weighted mean of 4.6 of all variables and was rated Strongly Agree in general. This implies that students have a positive response towards e-learning tool because they find the system easy to use and useful for their course work.
\end{abstract}

Keywords- Efficiency, Acceptability, e-learning tool, Technology Acceptance Model

\section{INTRODUCTION}

Computer as part of the innovation in technology manifest larger changes in the field of education. Educators are enthusiastic on searching for innovative, efficient, and realistic approaches that would assist students learning. They have attended several trainings and seminars on the revisions of instruction in order to meet up the desires of the students. Instructors are encouraged to make use of these innovative technological developments. Changes in technology have led to modifications in generally accepted educational perspective. According to Seattler (2004), "The historical function of educational technology is a process rather than a product." With the edge of technology, computers are now used as one means of instruction. Educators now have to give a second notion to the very nature of learning and also have to explore for unconventional learning and development solutions in concern of the rapid advancement of technologies. In the study of Chris Dede (2005) "Rapid advances in information technology are reshaping the learning styles of many students in higher education." As a result, advances in technology create new opportunities for higher education; emerging technologies can be used to deliver instruction matched to the learning styles of the new genre of students.

For numerous students, e-learning is the most appropriate means to pursue a degree in tertiary education. Thus, these students are more likely motivated to enroll in an e-learning class. Moreover, in e-learning classes, learners or students are open to register and accomplish work any time they want. According to Scott (2000) Carnegie Mellon University (CMU) in America, where e-Learning techniques have not only improved student exam results but have acted as educational bridges between subjects, breaking the ancient boundaries between disciplines. Furthermore, the inference is that higher education institutions which utilize effective eLearning methods not only enhance the performance of students in assessments but also produce graduates who are theoretically and practically prepared for working in an information age (Holley 2002).

Successful implementation of a system and adoption by learners requires a firm understanding of user acceptance processes and ways of persuading students to engage with these technologies (Abbad, 2009). Measuring the efficiency and acceptability of the e-learning has an important implication in analyzing end user acceptance. Regarding e-learning, Factors such as easiness in using software and good technical skills impact on student acceptance towards e-learning. As a result, the acceptability can be optimistic, if the new type of education fits the students' desires. Therefore, it is crucial to investigate issues that enlighten students' acceptance using e-learning Tool. As such, the purpose of this study is to scrutinize the impact of efficiency of the software on students and acceptability to use e-learning Tool in their education. 


\section{THEORETICAL FRAMEWORK}

The technology Acceptance Model (TAM) is adapted as a primary support for this study. The TAM has been and continues to be widely used by researchers to predict and explain user acceptance of information technologies. The purpose of this study is to examine the students' Acceptance of the e-learning Tool in the College of Computer Studies programs and to understand factors that will relate to technology acceptance. It is necessary to understand theories and models pertaining to the Technology Acceptance. Therefore, this study will bring in model that captures the realistic implications in due regards of the acceptance of a new system.

Hence, Wide-ranging theoretical frameworks are used to analyze the individual's acceptance of technologies. There have been several theories concerning the effectiveness of e-learning. Johnson et al. (2000) and Russell (2001) Further research by Davis, Bagozzi and Warshaw (1989) validated TAM as effective in predicting the acceptance of information technology in organizational contexts. TAM theorizes that an individual's intention to accept a technology depends on two beliefs: perceived usefulness and perceived ease of use, which influence computer users intentions and actual computer usage behaviour Yoonhyuk, J. (2009). Based on these two facets, users of any technology will always accept it, if it is deemed useful and is easy to use. Thus, the TAM is one of the most widely used technology adoption models and has been applied to different modes of technologies and user profiles (Jackson, Chow, Leich, 1997. The Perceived ease of use is defined as the degree to which the prospective user expects the potential system to be free of effort (Davis, 1989). Perceived usefulness is defined as a person's significant idea that using the technology will enhance his job performance. According to Zeithami, Parasuraman, Malhotra (2002), the ability to understand or apply innovation can be associated with perceived ease of use.

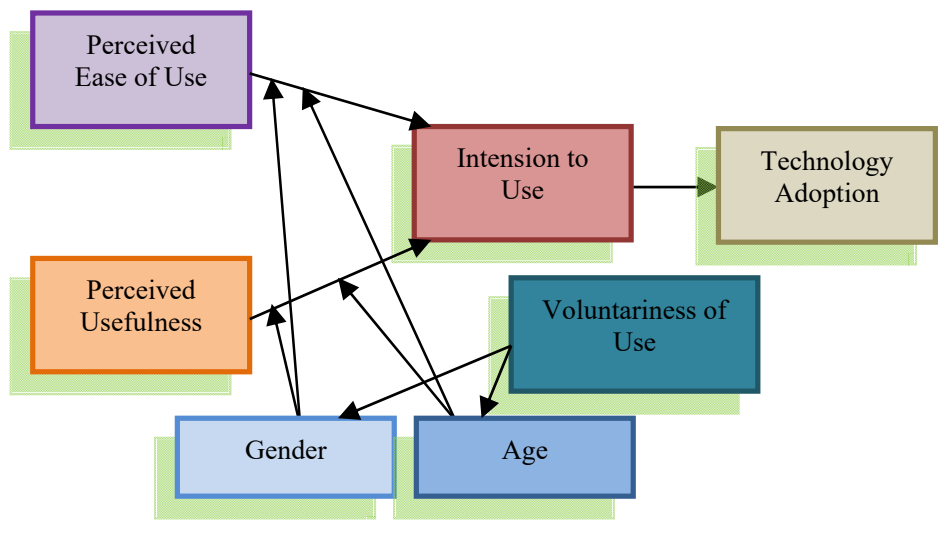

Figure 1. Technology Acceptance Model (TAM) Davis, Bagozzi and Warshaw (1989)

In this study the researcher's usefulness is defined as the level to which a student believes that utilizing of the elearning program will support or enhance him or her learning performance associated with the use of E-learning Tool. The ease of use is defined as the design quality of the e-learning is simple, elegant to view and easy to use and learn by the user. Based on the TAM, it is thought that the individual acceptance of e-learning program Portal will depend on whether or not the accessibility on e-learning program Portal is easy and effortless. In the study of Chiu, C., and Wang, Unified Theory of Acceptance and Use of Technology (UTAUT) Model does not take into consideration the age, gender, and voluntariness of use as factors in acceptance of e-Learning. Given that the study was experienced by the student respondents, consequently the demographic profile factor variable was dropped. This study will also focus on registered users of e-learning Tool in Eastern Samar State University Portal, therefore voluntariness of use variable will be dropped.

\section{METHOLOGY}

\section{A. Research Instrument}

The instruments used in gathering the data are the structured questionnaire and interview for the purpose of meeting the objectives of the study. As such, a Likert Scale is designed to examine how strongly subjects agree or disagree with statements on a five point scale with the following anchors: (5) Strongly Agree, (4) Agree, (3) Neither Agree or Disagree, (2) Disagree, (1) Strongly Disagree. The structured questionnaire was used to evaluate the e-learning system is based on (ISO 9126) Software Product Quality and (IBM) Usability Satisfaction. The researcher conducted interviews to concern students accompanied with the structured questionnaire to understand what the respondents observe on the current that they know concerning to e-learning system. This was used by the researcher in gathering data which is necessary to the acceptance of the student. 
Table of reference of Different Qualitative Description

Qualitative Description of the Students level of efficiency of the system

Scale Mean Score Interpretation

$5 \quad 5.00-4.50 \quad$ Strongly Agree

$4 \quad 4.49-3.50$ Agree

$3 \quad 3.49-2.50 \quad$ Neither Agree or Disagree

$2 \quad 2.49-1.50 \quad$ Disagree

$1 \quad 1.49-1.00 \quad$ Strongly disagree

Qualitative Description of the extent of acceptability of the e-learning system

Scale Mean Score Interpretation

$5 \quad 5.00-4.50 \quad$ Strongly Agree

$4 \quad 4.49-3.50$ Agree

$3 \quad 3.49-2.50 \quad$ Neither Agree or Disagree

$2 \quad 2.49-1.50$ Disagree

$1 \quad 1.49-1.00 \quad$ Strongly disagree

Table 1. Descriptive rating for the computed mean is as follows:

\begin{tabular}{|c|c|l|}
\hline Scale & Interpretation & \multicolumn{1}{|c|}{ Parameters } \\
\hline $4.50-5.00$ & Strongly Agree & $\begin{array}{l}\text { The respondents believed that e-learning tool is efficient. } \\
\text { The level of judgment was Strongly Agree or 100\% } \\
\text { favorable }\end{array}$ \\
\hline $3.50-4.49$ & Agree & $\begin{array}{l}\text { The respondents believed that e-learning Tool is efficient. } \\
\text { The level of judgment was Agree or } 80 \% \text { favorable }\end{array}$ \\
\hline $2.50-3.49$ & $\begin{array}{l}\text { Neither Agree or } \\
\text { Disagree }\end{array}$ & $\begin{array}{l}\text { The respondents believed that e-learning tool is efficient. } \\
\text { The level of judgment was Neither Agree or Disagree or } \\
50 \% \text { favorable }\end{array}$ \\
\hline $1.50-2.49$ & Disagree & $\begin{array}{l}\text { The respondents believed that e-learning tool is efficient. } \\
\text { The level of judgment was Disagree or 40\% favorable }\end{array}$ \\
\hline $1.00-1.49$ & Strongly Disagree & $\begin{array}{l}\text { The respondents believed that e-learning tool is efficient. } \\
\text { The level of judgment was Strongly Disagree or 20\% } \\
\text { favorable }\end{array}$ \\
\hline
\end{tabular}

To answer the question on the level of efficiency of the e-learning Tool, range of values was assigned to Descriptive rating indicated by each item.

Table 2. Descriptive rating for the computed mean is as follows:

\begin{tabular}{|c|c|l|}
\hline Scale & Interpretation & \multicolumn{1}{c|}{ Parameters } \\
\hline $4.50-5.00$ & Strongly Agree & $\begin{array}{l}\text { The respondents believed that e-learning tool is efficient. } \\
\text { The level of judgment was Strongly Agree or 100\% } \\
\text { favorable }\end{array}$ \\
\hline $3.50-4.49$ & Agree & $\begin{array}{l}\text { The respondents believed that e-learning Tool is efficient. } \\
\text { The level of judgment was Agree or } 80 \% \text { favorable }\end{array}$ \\
\hline $2.50-3.49$ & $\begin{array}{l}\text { Neither Agree or } \\
\text { Disagree }\end{array}$ & $\begin{array}{l}\text { The respondents believed that e-learning tool is efficient. } \\
\text { The level of judgment was Neither Agree or Disagree or } \\
50 \% \text { favorable }\end{array}$ \\
\hline $1.50-2.49$ & Disagree & $\begin{array}{l}\text { The respondents believed that e-learning tool is efficient. } \\
\text { The level of judgment was Disagree or 40\% favorable }\end{array}$ \\
\hline $1.00-1.49$ & Strongly Disagree & $\begin{array}{l}\text { The respondents believed that e-learning tool is efficient. } \\
\text { The level of judgment was Strongly Disagree or 20\% } \\
\text { favorable }\end{array}$ \\
\hline
\end{tabular}

To answer the question on the extent of acceptability of the e-learning Tool, range of values was assigned to Descriptive rating indicated by each item.

A. System Assessment

\section{RESULTS AND DISCUSSION}

This portion presents the table which describes the level of efficiency of the e-learning Tool during run time. The respondents of the study are the ESSU students from who they are direct beneficiaries of the system. 


\begin{tabular}{|c|c|c|c|c|c|c|c|}
\hline \multirow[b]{2}{*}{ Characteristics } & \multicolumn{5}{|c|}{ Level of Agreement } & \multicolumn{2}{|c|}{ Respondents $(n=375)$} \\
\hline & 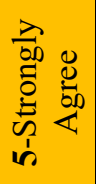 & 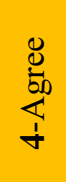 & 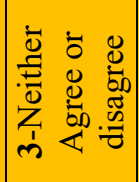 & 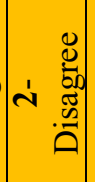 & 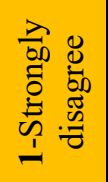 & 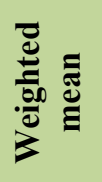 & Interpretation \\
\hline \multicolumn{8}{|c|}{ FUNCTIONALITY } \\
\hline Provide accounts to the user & 345 & 25 & 5 & 0 & 0 & 4.9 & $\begin{array}{l}\text { Strongly } \\
\text { Agree }\end{array}$ \\
\hline The system can generate report & 360 & 8 & 7 & 0 & 0 & 4.9 & $\begin{array}{l}\text { Strongly } \\
\text { Agree }\end{array}$ \\
\hline $\begin{array}{l}\text { The system allows the students view their } \\
\text { grades }\end{array}$ & 365 & 6 & 4 & 0 & 0 & 4.9 & $\begin{array}{l}\text { Strongly } \\
\text { Agree }\end{array}$ \\
\hline \multicolumn{8}{|c|}{ RELIABILTY } \\
\hline $\begin{array}{l}\text { Data is correct, clear and valid to the } \\
\text { intended audience }\end{array}$ & 368 & 5 & 2 & 0 & 0 & 4.9 & $\begin{array}{l}\text { Strongly } \\
\text { Agree }\end{array}$ \\
\hline $\begin{array}{l}\text { Assignments and exams were related to the } \\
\text { material taught in class and easy to access. }\end{array}$ & 360 & 10 & 5 & 0 & 0 & 4.9 & $\begin{array}{l}\text { Strongly } \\
\text { Agree }\end{array}$ \\
\hline $\begin{array}{l}\text { The information presented is relevant to } \\
\text { what the learner is supposed to know and } \\
\text { learn. }\end{array}$ & 343 & 18 & 11 & 3 & 0 & 4.8 & $\begin{array}{l}\text { Strongly } \\
\text { Agree }\end{array}$ \\
\hline \multicolumn{8}{|l|}{ fechin. } \\
\hline $\begin{array}{l}\text { The technology part of the course was well } \\
\text { organized, easy to navigate, and logical. }\end{array}$ & 323 & 26 & 16 & 8 & 2 & 4.7 & $\begin{array}{l}\text { Strongly } \\
\text { Agree }\end{array}$ \\
\hline $\begin{array}{l}\text { The system promotes interaction with the } \\
\text { students thru the system features embedded } \\
\text { such as forums and chat }\end{array}$ & 357 & 6 & 8 & 4 & 0 & 4.9 & $\begin{array}{l}\text { Strongly } \\
\text { Agree }\end{array}$ \\
\hline $\begin{array}{l}\text { The system will reduce the burden of the } \\
\text { teachers in the computation of grades. }\end{array}$ & 358 & 9 & 4 & 2 & 2 & 4.9 & $\begin{array}{l}\text { Strongly } \\
\text { Agree }\end{array}$ \\
\hline \multicolumn{8}{|c|}{ EFFICIENCY } \\
\hline $\begin{array}{l}\text { It efficiently responds to the users request } \\
\text { in terms of information they need. }\end{array}$ & 341 & 20 & 8 & 4 & 2 & 4.8 & $\begin{array}{l}\text { Strongly } \\
\text { Agree }\end{array}$ \\
\hline $\begin{array}{l}\text { It provides clarity or wording of } \\
\text { information. }\end{array}$ & 319 & 28 & 19 & 5 & 4 & 4.7 & $\begin{array}{l}\text { Strongly } \\
\text { Agree }\end{array}$ \\
\hline $\begin{array}{l}\text { Course requirements were stated clearly in } \\
\text { the syllabus. }\end{array}$ & 315 & 31 & 18 & 7 & 4 & 4.7 & $\begin{array}{l}\text { Strongly } \\
\text { Agree }\end{array}$ \\
\hline \multicolumn{8}{|c|}{$\begin{array}{l}\text { MAINTAINABILITY } \\
\text { MANA }\end{array}$} \\
\hline $\begin{array}{l}\text { The system enable modification is possible } \\
\text { at a minimal effort and time }\end{array}$ & 321 & 21 & 13 & 9 & 11 & 4.6 & $\begin{array}{l}\text { Strongly } \\
\text { Agree }\end{array}$ \\
\hline $\begin{array}{l}\text { The system adhere to standards, } \\
\text { conventions or regulations relating to } \\
\text { maintainability }\end{array}$ & 318 & 23 & 14 & $\begin{array}{l}1 \\
2\end{array}$ & 8 & 4.6 & $\begin{array}{l}\text { Strongly } \\
\text { Agree }\end{array}$ \\
\hline \multicolumn{8}{|c|}{ PORTABILITY } \\
\hline $\begin{array}{l}\text { The system can co-exist with other } \\
\text { independent software in a common } \\
\text { environment sharing }\end{array}$ & 315 & 26 & 24 & 7 & 3 & 4.7 & $\begin{array}{l}\text { Strongly } \\
\text { Agree }\end{array}$ \\
\hline $\begin{array}{l}\text { The system can be adapted for different } \\
\text { specified environment }\end{array}$ & 317 & 22 & 25 & 7 & 4 & 4.7 & $\begin{array}{l}\text { Strongly } \\
\text { Agree }\end{array}$ \\
\hline
\end{tabular}

Table 3. Data on the level of efficiency of the e-learning tool in terms of functionality, reliability, usability, efficiency, maintainability and portability. 


\begin{tabular}{|c|c|c|}
\hline \multirow{2}{*}{ Characteristics } & \multicolumn{2}{|c|}{ Respondents (n=375) } \\
\cline { 2 - 3 } & $\begin{array}{c}\text { Average weighted } \\
\text { Mean }\end{array}$ & Interpretation \\
\hline Functionality & $\mathbf{4 . 9}$ & Strongly Agree \\
\hline Reliability & $\mathbf{4 . 8}$ & Strongly Agree \\
\hline Usability & $\mathbf{4 . 8}$ & Strongly Agree \\
\hline Efficiency & $\mathbf{4 . 7}$ & Strongly Agree \\
\hline Maintainability & $\mathbf{4 . 6}$ & Strongly Agree \\
\hline Portability & $\mathbf{4 . 7}$ & Strongly Agree \\
\hline Overall weighted & $\mathbf{4 . 7}$ & Strongly Agree \\
Mean & & \\
\hline
\end{tabular}

Table 4. Summary of data on the level of efficiency of the e-learning tool.

The table above shows the summary of the overall weighted mean of the level of efficiency of the e-learning Tool which rated as 4.7(SA). The variables namely; Functionality obtained a result of a weighted mean of 4.9(SA), 4.8 (SA) for Reliability, 4.8(SA) for Usability, 4.7(SA) for Efficiency, 4.6 (SA) for Maintainability and for Portability 4.7(SA). The variables were rated Strongly Agree (SA) in general. In this study, the result has shown the positive response of the respondents in all areas in terms of efficiency Evaluation of the e-learning tool.

\subsection{Acceptance Evaluation}

This portion presents the table which describes the extent of acceptance testing of the e-learning tool of the respondents.

\subsection{Acceptance Evaluation result}

\begin{tabular}{|c|c|c|c|c|c|c|c|}
\hline \multirow[b]{2}{*}{ Criteria Evaluated } & \multicolumn{5}{|c|}{ Level of Agreement } & \multicolumn{2}{|c|}{ Respondents $(\mathrm{n}=\mathbf{3 7 5})$} \\
\hline & 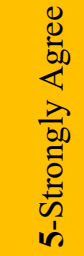 & 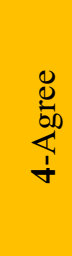 & 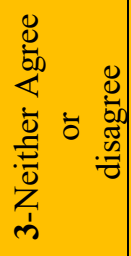 & 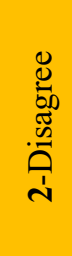 & 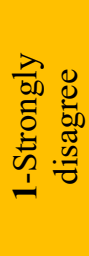 & 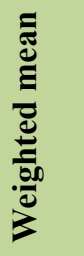 & Interpretation \\
\hline It was simple to use this system & 316 & 25 & 12 & 13 & 9 & 4.6 & Strongly Agree \\
\hline $\begin{array}{l}\text { I can effectively complete the tasks } \\
\text { using this system }\end{array}$ & 311 & 28 & 16 & 13 & 7 & 4.6 & Strongly Agree \\
\hline $\begin{array}{l}\text { I am able to complete my work } \\
\text { using this system }\end{array}$ & 320 & 21 & 17 & 10 & 7 & 4.6 & Strongly Agree \\
\hline I feel comfortable using this system & 313 & 23 & 15 & 14 & 10 & 4.6 & Strongly Agree \\
\hline $\begin{array}{l}\text { It was easy to learn to use this } \\
\text { system }\end{array}$ & 308 & 30 & 14 & 15 & 8 & 4.6 & Strongly Agree \\
\hline $\begin{array}{l}\text { Whenever I make a mistake using } \\
\text { the system, I recover easily and } \\
\text { quickly }\end{array}$ & 298 & 27 & 23 & 21 & 6 & 4.5 & Strongly Agree \\
\hline $\begin{array}{l}\text { The organization of the } \\
\text { information on the system is clear }\end{array}$ & 301 & 22 & 23 & 17 & 12 & 4.5 & Strongly Agree \\
\hline $\begin{array}{l}\text { The interface of this system is } \\
\text { pleasant }\end{array}$ & 319 & 19 & 15 & 18 & 4 & 4.6 & Strongly Agree \\
\hline $\begin{array}{l}\text { I like using the interface of this } \\
\text { system }\end{array}$ & 322 & 22 & 10 & 12 & 9 & 4.6 & Strongly Agree \\
\hline $\begin{array}{l}\text { Overall, I am satisfied with how } \\
\text { easy it is to use this system }\end{array}$ & 318 & 18 & 15 & 17 & 7 & 4.6 & Strongly Agree \\
\hline Average & eighte & Mean & & & & 4.5 & Strongly Agree \\
\hline
\end{tabular}

Table 5. Data on the extent of acceptability of the e-learning tool. 
To answer the extent of acceptability of the e-learning tool majority of the students highly evaluated and tested as "Strongly Agree" and acceptable instructional tool in students learning. In relation, the acceptability of the elearning tool the variables were evaluated and the table above reveals the average weighted mean of the system evaluation were 4.5 which rated as "Strongly Agree" in general. In this study, the result has shown the positive response of the respondents in all areas in terms of acceptability Evaluation of the e-learning tool.

\section{CONCLUSION}

This study investigates the level of efficiency and acceptability of the e-learning tool. Given the result obtained by the researcher it can be safely concluded that the students were optimistic towards e-learning tool because they find the system easy to use and useful for their course work. This study indicates that e-learning was more challenging to students who persist in the virtual environment than in the face-to-face classroom instruction.

\section{References}

[1] Al-Harbit, K. Informatics 2011. e-learning in the Saudi tertiary education: Potential and challenges, Applied Computing \&

[2] Lee, B., Yoon, J., \& Lee, I. 2009. Learners' acceptance of e-learning in South Korea: Theories and results. Computers \& Education.

[3] Venkatesh, V. and Bala, H. 2008.Technology Acceptance Model 3 and a Research Agenda on Interventions.

[4] Nafukho, F. 2007. The place of e-learning in Africa's institutions of higher learning.

[5] Koohang, A. 2004. A study of users' perceptions towards e-learning courseware usability, International Journal on E-learning.

[6] Davis, F.D. 1989. Perceived usefulness, perceived ease of use, and user acceptance of information technology.

[7] Chris Dede. 2005 "Rapid advances in information technology are reshaping the learning styles of many students in higher education.".

[8] Seattler . 2004 "The historical function of educational technology is a process rather than a product.".

[9] Elain Allen and Jeff Seaman. 2009. Learning on Demand: Online Education in the United States.

[10] Marcial, D.E. 2012.Teaching and Learning with Technology in higher education institutions in the Philippines.

[11] Moore, M. G., \& Thompson, M. M. 1997. The Effect of Distance Learning,

[12] Anna Ya Ni, 2012. Comparing the Effectiveness of Classroom and Online learning: Teaching Research Methods. 